\title{
Penggunaan Handphone Pada Remaja Terhadap Interaksi Sosial
}

\author{
Arfan Suryadi ${ }^{1}$, Galuh Alif Ranchman ${ }^{2}$, Ressa Putri Amelia ${ }^{3}$, Tiara Citra Rahayu ${ }^{4}$
}

Program Studi IImu Komunikasi, Fakultas IImu Komunikasi, Universitas Islam Nusantara Bandung

$\begin{array}{r}\hline \text { A R T I C L E I N F O } \\ \hline \text { Article history: } \\ \text { Received Oct 22, } 2021 \\ \text { Revised Nov 11, } 2021 \\ \text { Accepted Nov 28, } 2021 \\ \hline\end{array}$

\section{Keywords:}

Handphone;

Remaja; Interaksi Sosial.

\begin{abstract}
In the current era of globalization where changes in technology and the flow of information are increasingly advanced and fast encouraging people to better understand the sophistication of technology Mobile is a two-way electronic telecommunication tool that can be carried everywhere and has the ability to send messages in the form of voice, picture, video and video messages. etc. Mobile phones can also change family life, work environment, school, friendship, religious activities, politics, and so on are all affected by communication technology. Positive influences include facilitating communication even though they are far away, making it easier to find information and so on. While the negative effects generated by the use of cellphones include the dangers resulting from using cellphones too often, teenagers are more likely to prefer communicating through the media rather than communicating faceto-face directly.
\end{abstract}

\section{ABSTRAK}

Di era globalisasi sekarang ini dimana perubahan teknologi dan arus informasi yang semakin maju dan cepat mendorong masyarakat untuk lebih memahami kecanggihan teknologi Handphone merupakan alat telekomunikasi elektronik dua arah yang bisa dibawa kemana-mana dan memiliki kemampuan untuk mengirimkan pesan berupa suara, pesan gambar, video dan lainlain . Handphone juga bisa merubah Kehidupan keluarga, lingkungan kerja, sekolah, pertemanan, kegiatan keagamaan, politik, dan sebagainya semua terpengaruh teknologi komunikasi . Pengaruh positif di antaranya adalah memudahkan komunikasi walau berada jarak jauh, memudahkan dalam mencari informasi dan lain sebagainya. Sedangkan pengaruh negatif yang dihasilkan oleh penggunaan handphone di antaranya adalah bahayanya yang dihasilkan dari pemakaian handphone yang terlalu sering, remaja lebih cenderung menyukai berkomunikasi melalui media dari pada berkomunikasi secara tatap muka langsung.

This is an open access article under the CC BY-NC license.

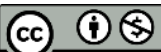

\section{Corresponding Author:}

Ressa putri amelia

Program Studi Ilmu Komunikasi, Fakultas IImu Komunikasi,

Universitas Islam Nusantara Bandung,

Jl. Soekarno-Hatta No.530, Sekejati, Kota Bandung, Jawa Barat 40286

Email: ressaputriamelia043@gmail.com

\section{PENDAHULUAN}

Zaman sekarang banyak hal yang bisa di permudah oleh teknologi, dengan adanya teknologi handphone kita bisa mengirim pesan dengan cepat dan akurat. Akan tetapi banyak dampak positif dan negative dari penggunaan handphone. Peran orang tua sangat di butuhkan untuk membimbing anak anak agar terarahkan ke arah yang positif. Banyak anak anak dan remaja yang salah pergaulan lewat teknologi ini karna kurangnya wawasan. Kemajuan ilmu teknologi pada saat 
ini memberikan perubahan besar pada dunia. Hal tersebut dapat dilihat dari berbagai sisi, meliputi perubahan di bidang kesehatan, pendidikan, hiburan, komunikasi, serta akses informasi yang begitu mudah Kemudahan memperoleh informasi membuat manusia lebih cepat mengetahui berita yang sedang terjadi misalnya, masyarakat yang ada di Indonesia dapat dengan mudah mengikuti perkembangan piala dunia tahun 2014 hanya dengan menggunakan gadget Indah, Dwi Iswanti (2020).

Sebagai makhluk sosial kita tidak bisa menghindar dari tindakan komunikasi menyampaikan dan menerima pesan dari dan ke orang lain tindakan komunikasi terus menerus terjadi selama proses kehidupan. Komunikasi menjadi penting karena, fungsi yang bisa di rasakan oleh pelaku komunikasi tersebut. Melalui proses komunikasi seseorang menyampaikan apa yang ada dalam benak pikiran nya dan perasaan hati nurani nya kepada orang lain, baik secara langsung maupun tidak langsung. Melalui komunikasi seseorang dapat membuat dirinya tidak merasa terasing atau terisolasi dari lingkungan sekitarnya. Hertmada,Sinta Kendek (2017).

Banyak masyarakat yang menggantungkan masa depannya kepada kalangan remaja. Remaja merupakan bagian penduduk yang berskala kecil, namun memiliki sumbangan teramat besar. Penting memahami para remaja karena remaja adalah masadepan setiap masyarakat. Masa remaja merupakan suatu fase perkembangan antara masa kanak-kanak dan masa dewasa. Berlangsung antara usia 12-24 tahun. Muflih (2017). Di era teknologi yang semakin berkembang pesat ini, banyak hal mulai bergeser dan membentuk sebuah gaya hidup baru, di mana teknologi menjadi salah satu kebutuhan pokok dalam keseharian manusia. Teknologi sudah mengubah cara hidup manusia dalam berbagai bidang kehidupan. Dimulai dari proses pembelajaran, komunikasi antar manusia, bisnis, hiburan, dan lainnya Prasetya,Bernadus Wisnu (2017). Kemajuan teknologi saat ini tidak bisa dipisahkan dari kehidupan masyarakat. Berbagai informasi yang terjadi di berbagai belahan dunia kini telah dapat langsung diketahui berkat kemajuan teknologi (gobalisasi). Di era globalisasi sekarang ini dimana perubahan teknologi dan arus informasi yang semakin maju dan cepat mendorong masyarakat untuk lebih memahami kecanggihan teknologi. Al-ljtimaiyyah (2018) banyak spekulasi tentang teknlogi salah satunya HP (Handphone). Dari jurnal yang kami kutip, Handphone adalah barang canggih yang diciptakan dengan berbagai aplikasi yang dapat menyajikan berbagai media seperti berita, jejaring sosial, hobi,bahkan hiburan, ini adalah salah satu tanda kemajuan dari teknologi. Meningkatnya penggunaan gadget atau alat-alat yang dapat dengan mudah maka terkoneksi dengan internet ini, mengalami peningkatan dari waktu ke waktu Bewu,Yuliana (2019).

Handphone juga bisa merubah Kehidupan keluarga, lingkungan kerja, sekolah, pertemanan, kegiatan keagamaan, politik, dan sebagainya semua terpengaruh teknologi komunikasi. Interaksi manusia dengan manusia telah digantikan menjadi interaksi manusia dan seringkali tidak disadari teknologi dapat mengurangi interaksi seseorang secara langsung dengan orang-orang terdekat yang ada di sekitar (misalnya antara orang tua dan anak di rumah masingmasing sibuk dengan gadget-nya). Saling tegur sapa dengan menghadapkan senyum pada tetangga semakin berkurang, sedangkan sibuk sendiri di hadapan komputer dan alat teknologi lainnya sudah dianggap lumrah di masyarakat saat ini. Al-ljtimaiyyah (2018) hal ini juga menjadi dampak negative penggunaan handphone Sebelum adanya handphone,gadget dan perangkat elektronik lainnya, orang-orang dengan mudah saling menyapa dan berinteraksi pada saat bertemu atau pada saat berkumpul. Pada saat ini orang lebih asik dan sibuk dengan gadget 3 yang dimilikinya. Orang-orang saat ini cenderung lupa dengan adanya teman yang sesungguhnya ada disampingnya. Prasetyo, Rahmad Adi (2017). Dengan adanya permasalahan ini kami dari kelompok 3 ingin menemukan solusi dan hal-hal baru dalam kehidupan zaman sekarang. Banyak hal yang menarik tentang bagaimana kelangsungan hidup di zaman elektronika dimana semua hal dapat dengan mudah di kerjakan.

\section{METODE PENELITIAN}

Metode peneletian ini menggunakan metode kualitatif, Penelitian kualitatif adalah metode yang melibatkan suatu pendekatan interpretative yang mewajibkan pada pokok permasalahannya, dan juga penelitian ini bekerja secara alami yang memahami dan juga memberikan tafsiran yang ada pada masyarakat. Penelitian adalah penyelidikan dari suatu bidang ilmu pengetahuan yang dijalankan untuk memperoleh fakta-fakta atau prinsip dengan sabar, hati-hati, dan sistematis Umar Sidiq (2019). Teknik pengambilan sampel dilakukan secara random, pengumpulan data 
menggunakan instrumen penelitian, Kuisioner adalah cara pengumpulan informasi dalam jumlah besar yang relative murah,cepat dan efisien,dengan kuisioner kita juga bisa mendapatkan data dari sample orang banyak. Pengumpulan datanya juga relative cepat karna peneliti tidak perlu hadir pada saat pengisian kuisioner. Hal ini berguna untuk meneliti populasi besar,dimana wawancara bukan pilihan yang praktis. Penelitian ini dilakukan pada bulan 08 Juni 2021 sampai dengan 30 juni 2021 yang diawali dengan memberikan kuisioner dan dilanjutkan dengan wawancara mendalam, serta dokumentasi sebagai bukti bahwa penulis sudah melakukan penelitian di kampus Universitas Islam Nusantara dan di desa sukamanah. Adapun informan yang kami jadikan sumber informasi adalah 25 orang remaja dan 15 diantaranya mahasiswa uninus

\section{PEMBAHASAN}

Handphone merupakan alat telekomunikasi elektronik dua arah yang bisa dibawa kemana-mana dan memiliki kemampuan untuk mengirimkan pesan berupa suara, pesan gambar, video dan lainlain. Pengertian tersebut merupakan pengertian handphone secara umum. Kehadiran handphone merubah sistem komunikasi masyarakat yang dulunya kebanyakan dilakukan secara tatap muka, namun pada saat ini sistem komunikasi masyarakat mulai berpindah dari sistem komunikasi lama (tatap muka) menjadi sistem komunikasi baru yaitu melalui handphone. Perkembangan handphone dalam masyarakat makin hari makin meningkat, mulai dari fasilitas yang disediakan sampai bentuknya yang besar hingga yang kecil. Banyak fasilitas-fasilitas baru yang ada dalam handphone, tidak hanya sebatas mengirim pesan atau telepon saja, tetapi juga bisa digunakan sebagai browsing internet, menonton, foto, video dan masih banyak lagi. Keberadaan handphone saat ini di anggap sebagai barang kebutuhan yang sangat diperlukan bagi setiap orang, sehingga setiap orang harus memiliki alat komunikasi handphone sebagai alat penunjang kebutuhan berinformasi dan memudahkan masyarakat dalam aktifitas sehari-hari. Komunikasi diperlukan untuk menjalin suatu interaksi dalam masyarakat.

Dalam penelitian kelompok kami tentang peran handphone untuk masyarakat khususnya kalangan muda dan beberapa orang dari kelas $A$. Kami mendapatkan masukan atau hal hal yang cenderung bertengtangan antara narasumber akan tetapi banyak juga yang sependapat. Dalam hal ini kami mengajukan pertanyaan seperti apakah handphone itu penting? Dari 25 orang yang kami jadikan narasumber atau responden $96 \%$ setuju bahwa handphone untuk zaman sekarang sangatlah penting. Dan 4\% tidak setuju akan kepentingan handphone untuk zaman sekarang. Akan tetapi mereka juga setuju bahwa penggunaan hanphone harus di batasi, mengingat efak yang akan di timbulkan jika terus menerus menatap layar handphone, sebanyak $88 \%$ setuju penggunaan handphone harus dibatasi dan $12 \%$ tidak setuju bahwa handphone harus dibatasi. Teknologi hanphone digunakan oleh para narasumber selama kurang lebih 8 jam, $40 \%$ mereka menggunakan hanphone lebih dari 8 jam dan $80 \%$ mereka menggunakan handphone kurang dari 8 jam.

Sudah terbukti bahwa handphone sangatlah penting untuk kehidupan zaman sekarang, petanyaan yang kami ajukan bahwa apakah setiap aktivitas responden memerlukan handphone jawaban mereka adalah 52\% setuju bahwa handphone bisa mempermudah aktivitasnya sedangkan $40 \%$ dari mereka juga menyatakan bahwa setiap aktivitas tidak memerlukan handphone dan sisanya menjawab tidak selalu karna kegiatan bukan dari handphone saja. akan tetapi $88 \%$ narasumber setuju bahwa handphone dapat menimbukan efek samping yang cukup berbahaya dan beberapa orang juga menambahkan bahwa ketika terlalu lama menggunakan handphone akan menimbulkan sakit kepala dan sakit mata.

Pada zaman sekarang teknologi sangat mudah di akses, semua kalangan dapat menggunakan teknologi dengan sangat mudah. Akan tetapi ada beberapa pertengtangan akan perihal kecanduan anak di bawah umur terhadap handphone. Dan ini beberapa pendapat tentang anak di bawah umur tetapi sudah kecanduan teknologi handphone:

Tabel 1. Pendapat kecanduan HP pada anak dibawah umur

Pro
Selagi di pakai terhadaphal hal yang positif itu




\begin{tabular}{ll}
\multicolumn{1}{c}{ Pro } & \multicolumn{1}{c}{ Kontra } \\
\hline $\begin{array}{l}\text { peran orang tua sangatlah penting dalam } \\
\text { membatasi akses internet anak. }\end{array}$ & \\
$\begin{array}{l}\text { Tidak apa apa asalkan tidak terpengaruh oleh } \\
\text { hal hal kurang baik di luar sana. }\end{array}$ & $\begin{array}{l}\text { Harusnya jangan di beri akses internet terlebih } \\
\text { dahulu, karna banyak anak di bawah umur perlu } \\
\text { bersosialisasi dengan temen sebayanya. }\end{array}$ \\
$\begin{array}{l}\text { Kita harus beradaptasi akan teknologi zaman } \\
\text { sekarang. }\end{array}$ & $\begin{array}{l}\text { Mengenaskan, apa lagi hanya untuk di pakai bermain } \\
\text { game. }\end{array}$ \\
& $\begin{array}{l}\text { Sulit di ajak kearah yang lebih baik, karna sudah } \\
\text { terpengaruh terhadap teknologi. }\end{array}$ \\
\hline
\end{tabular}

Simpulan dari pernyataan diatas: bahwa banyak kalangan muda dan beberapa orang dari kelas $\mathrm{A}$ tidak setuju akan anak yang dibawah umur sudah kecanduan bermain handphone dan peran orang tua harus sangat di perhatikan. Hal ini juga di dukung Kwon,dkk menjelaskan bahwa handphone addiction adalah suatu perilaku kecanduan atau keterikatan terhadap handphone yang memungkinkan terjadinya masalah social seperti menarik diri dan kesulitan dalam aktivitas seharihari.

Peran orang tua terhadap membimbing anak masih perlu perhatian lebih, dari 23 jawaban responder banyak yang setuju bahwa orang tua masih banyak yang membiarkan anaknya bermain hanphone tanpa arahan dari orang tua, alhasil banyak anak usia 7-15 tidak paham arti dari penggunaan hanphone yang baik dan benar, banyak kalangan anak muda yang terjerumus kedalam hal-hal negative. Contohnya dalam kasus freestyle yang ada dalam game FREE FIRE banyak kalangan anak muda yang mempraktekannya dalam kehidupan sehari hari. Dan hal ini seperti lumrah terjadi pada saat ini.

Tabel 2. Dampak negative dan positif penggunaan handphone menurut responden

\begin{tabular}{|c|c|}
\hline Positif & Negative \\
\hline Mempermudah aktivitas. & Bisa menimbulkan rasa ketergantungan. \\
\hline $\begin{array}{l}\text { Dapat mengirim pesan dengan jarak yang jauh } \\
\text { dan cepat. }\end{array}$ & $\begin{array}{l}\text { Bisa melupakan akan hal yang terjadi pada } \\
\text { lingkungan sekitar. }\end{array}$ \\
\hline $\begin{array}{l}\text { Bisa mengetahui hal hal yang baru yang kita tidak } \\
\text { tahu. }\end{array}$ & $\begin{array}{l}\text { Radiasi yang mengakibatkan kesehatan } \\
\text { terganggu. }\end{array}$ \\
\hline Menjadikan media hiburan. & Menjadikan seseorang menjadi introvert \\
\hline $\begin{array}{l}\text { Dapat mencari hal hal tentang Kesehatan,berita } \\
\text { terbaru dan lain lain. }\end{array}$ & Kekerasa, hoaks,pornografi. \\
\hline Komunikasi tidak terbatas. & Prestasi akademik menjadi turun. \\
\hline
\end{tabular}

Sampai saat ini penggunaan handphone menjadi hal yang sering di perdebatkan. Kesimpulannya dari kelompok kami adalah penggunaan handphone akan bermanfaat bagi mereka yang menfaatkannya dan juga sebaliknya. Dalam hal ini teknologi menjadi hal yang bisa membuat kita menjadi seseorang yang baik dan buruk, tergantung kita memanfaatkannya. Saran dan masukan terhadap penggunaan handphone pada zaman sekarang : (a). Lakukan dalam hal yang positif dan batasi penggunaan. (b). Perbanyak aktivitas tanpa menggunakan handphone. (c). Gunakan handphone dengan secukupnya saja. (d). Lebih bijak dalam berkomunikasi. (e). Lebih ke arah positif dan tinggalkan hal hal yang negative.

\section{KESIMPULAN}

Penggunaan handphone sangat berpengaruh terhadap interaksi sosial remaja baik pengaruh positif maupun pengaruh negatif. Pengaruh positif di antaranya adalah memudahkan komunikasi walau berada jarak jauh, memudahkan dalam mencari informasi dan lain sebagainya. Sedangkan pengaruh negatif yang dihasilkan oleh penggunaan handphone di antaranya adalah bahayanya yang dihasilkan dari pemakaian handphone yang terlalu sering, remaja lebih cenderung menyukai berkomunikasi melalui media dari pada berkomunikasi secara tatap muka langsung. Selanjutnya, handphone dapat menjadikan remaja mengalami disfungsi, waktu interaksi tatap muka langsung berkurang, kehadiran handphone mengganggu kualitas interaksi langsung, handphone menjadikan remaja hyperpersonal, handphone menjadikan remaja konsumtif dan handphone membuat remaja kurang peka terhadap lingkungan sekitar. Faktor penghambat pola interaksi sosial remaja adalah faktor lingkungan keluarga, masyarakat, keagamaan, adat istiadat dan kebiasaan. Faktor-faktor ini 
dapat menjadikan perubahan sosial pada remaja pada khususnya dan masyarakat pada umumnya.

\section{Referensi}

Istifahadah, R. (2018) dampak penggunaan handphone terhadap peserta didik di SMA Piri Kecamatan Jatiagung Kabupaten Lampung Selatan (Doctoral dissertation, UIN Raden Intan Lampung).

Syukri, M. U., \& Logahan, J. M. (2019). Dampak Penggunaan Gadget Terhadap Interaksi Sosial Pada Remaja Karang Taruna Kelurahan Karet Kuningan. Jurnal Sistem Informasi, 1(2). $28-29$

Trisdiana, L. (2019). Hubungan Antara Fear Of Missing Out Dengan Penggunaan Smartphone Yang Bermasalah Pada Mahasiswa. Doctoral Dissertation. Surabaya: Universitas Airlangga. 12-14

Aziz, M., \& Nurainiah, N. (2018). Pengaruh Penggunaan Handphone Terhadap Interaksi Sosial Remaja Di Desa Dayah Meunara Kecamatan Kutamakmur Kabupaten Aceh Utara. Jurnal Al-Ijtimaiyyah: Media Kajian Pengembangan Masyarakat Islam, 4(2). 29-30

Bewu, Y., Dwikurnaningsih, Y., \& Windrawanto, Y. (2019). Pengaruh Penggunaan Gadget Terhadap Interaksi Sosial Pada Siswa Kelas X Ips Sma Kristen Satya Wacana Salatiga. Psikologi Konseling, 15(2). 463467

Muflih, M., Hamzah, H., \& Purniawan, W. A. (2017). Penggunaan smartphone dan interaksi sosial pada remaja di SMA Negeri I Kalasan Sleman Yogyakarta. Idea Nursing Journal, 8(1), 13-15

Gultom, J. (2016). Pengaruh Penggunaan Gadget Terhadap Interaksi Sosial Anak Remaja Di Desa Batunadua Kecamatan Pangaribuan Kabupaten Tapanuli Utara. Doctoral dissertation. Medan: UNIMED. 5-7

Olifia, S., \& Nuraini, D (2017). Komunikasi Keluarga Dalam Mencegah Dampak Negatif Penggunaan Gadget. Jakarta Selatan 113-115

Prasetya, B. W. (2017). Hubungan Antara Kecanduan Gadget Dan Empati Pada Remaja Akhir Di

Hati Kudus Tuhan Yesus Simo Kabupaten Boyolali . Doctoral dissertation, Universitas Negeri

Semarang. 7-9

Rini, M. K., \& Huriah, T. (2020). Prevalensi dan Dampak Kecanduan Gadget Pada Remaja: Literature Review. Jurnal Keperawatan Muhammadiyah, 5(1). 191-193. 